\title{
The Analysis Factor of Self-Confidence of Buddhist Religious Teachers in Indonesia
}

\section{Hesti Sadtyadi}

Dr., Department of Buddhist Religious Education, Buddhist College Raden Wijaya, Wonogiri, Indonesia, 15hestisadtyadi@gmail.com

Indonesian Buddhist religious teachers face various problems related to the limitation of learning infrastructure and the availability teacher training program that affects their self-confidence. This research aims to analyse the factors and the indicators of self-confidence of Buddhist religious teachers as the basis for the development of teacher self-confidence and professionalism. The proposed research questions are about (1) what are the factors as well as the indicators of the self-confidence of the Buddhist religious teachers in performing their tasks and (2) how strong are its indicators affecting teachers' self-confidence? The research participants were 153 Buddhist religious teachers who teach at formal schools. The results of the research show that factors affecting the self-confidence of Buddhist religious teachers in Indonesia are classroom environment and learning material and also teachers' working time and additional tasks. The four dominant indicators of the classroom environment and learning material are teachers' perception toward the availability of learning material, classroom availability, the quality of learning the infrastructure, and teachers' perception toward infrastructure policy. The four dominant indicators of teachers' working time and additional tasks are teachers' perception regarding a load of working time, the load of teachers' working time, teachers' perception regarding a load of their additional tasks, and the load of teachers' additional tasks.

Keywords: self-confidence, Buddhist teachers, classroom environment, teachers' working time, teachers

\section{INTRODUCTION}

Teachers' self-confidence takes an important role in the development of teachers' skills and professionalism. Teachers' self-confidence can be broadly defined as teachers' belief in the possibility of success. Theoretically, self-confidence can be categorized as the teachers' personal skill. Some scholars had pointed out that self-confidence corresponds with other pedagogical aspects especially teachers' professional skills. As pointed out by Appleton (1995), self-confidence can affect the teachers' competency to

\footnotetext{
Citation: Sadtyadi, H. (2020). The Analysis Factor of Self-Confidence of Buddhist Religious Teachers in Indonesia. International Journal of Instruction, 13(2), 587-600. https://doi.org/10.29333/iji.2020.13240a
} 
teach the subject matter. Self-confidence correlates with personal motivation in pursuit of their objectives (Benabout \& Tirole, 2002). In addition, teachers' self-confidence relates to teaching techniques (Calabio et al, 2017). Self-confidence determine the construction of teachers' personal and professional skills (Çiftçi \& Yildiz, 2019).

Based on the previous research (Appleton \& Kindt, 1999; Appleton, 1995; Martin, 2006; Lemon \& Garvis, 2019), the lack of confidence seems to be a common problem for teachers' professional competency development. The teachers who deficit in confidence might face burnout in which they were stressed by their tasks and obligations (Maslach \& Jackson, 1996). The symptoms of burnout can be shown in teachers' apathy, frustration, degraded spirit of teaching and fulfil their tasks, dissatisfaction, absenteeism, and employee turnover ( $\mathrm{Yu}$ et al, 2015). It means that if teachers have a lack of self-confidence, they would face trouble in teaching or developing their competency.

Indonesian Buddhist teachers also have problems with their self-confidence and, at a certain degree feel burnout (Usman, 2004). In the Indonesian education system, Buddhism is categorized as one of the religious subjects that should be learned in formal education besides other religions such as Islam, Christianity, and Hinduism. Buddhist religious teachers only teach in religious Buddhist subject learning. Buddhism is only learned by Buddhist students and not all of the schools in Indonesia have students who believe in Buddhism. Consequently, only a few Buddhist religious teachers employed in one region because of the limited number of schools that held Buddhist subjects. It forces the teachers to teach outside of their schools especially in some remote areas. This situation affects the teachers' working load and their professional development.

The current curriculum of Indonesian education, the 2013 Curriculum (K13), has accommodated the practice of Buddhist education from elementary school to secondary schools. However, the problems in the practice of Buddhist education are stills remain. The practice of Buddhist education and teaching in Indonesia faces some practical problems at the level of teachers' professionalism, policy decision, the infrastructure of learning, and the learning process. From 2007 to 2011, some Buddhist religious teachers have been certified for their professionalism by the Indonesian government. However, the Indonesian government stopped the certification program for Buddhist teachers from 2011 to 2018. Consequently, the pre-service teachers who graduated from Buddhist Higher Education Institution could not fulfil the requirements to be called the professional teacher (Satdyadi, 2019).

Besides professionality, the delay for teacher's certification program represents the tardiness of policy decision to evolve Buddhist teachers' competency. However, at the same time, Buddhist teachers are forced to have a good quality of teaching based on the standard of professionalism. Another crucial problem lies in the availability of infrastructure to teach Buddhist at formal education. Most of the Buddhist teaching in formal education had not been supported by adequate learning infrastructures such as classroom and learning material availability. This problem makes the practice of Buddhist teaching in formal education could not be fully implemented. The teacher and students have to make an appointment to manage the extended learning class. 
Consequently, almost $60 \%$ of Buddhist learning process could not be held according to the predetermined schedule (Satdyadi, 2018).

Certainly, that problem affects the learning process of Buddhist education. Those problems can result in a working pressure for the teachers' self-confidence in teaching Buddhist in the classroom. However, the problem of self-confidence could not be simplified by perceiving a common understanding of Buddhist religious education practices. It is because the Indonesian Buddhist teachers have a specific background of the problem. Therefore, further analysis should be initiated to examine the factor and indicator of the self-confidence of Indonesian Buddhist teachers.

Based on this background, it can be assumed that Indonesian Buddhist religious teachers might have a problem with their self-confidence. Yet until today, none of the scholars discusses this problem. Therefore, this research becomes important to initiate the study of teachers' self-confidence, which is related to teacher's personal and professional skills, especially in the context of research on the Buddhist religious education teacher in Indonesia. The author believes that the construction of teachers' self-confidence, particularly in the case of Indonesian Buddhist teachers, needs to analysed more deeply to reveal its factors and indicators. Therefore, this research aims to examine the factors and the indicators of the self-confidence of Buddhist religious teachers in Indonesia. The proposed research questions are (1) what are the factors as well as the indicators of the self-confidence of Buddhist religious teacher in performing their tasks and (2) how strong are its indicators affecting teachers' self-confidence?

\section{Teachers' Self-Confidence}

Self-confidence is a person's belief in the possibility of success. Self-confidence is context-specific toward a particular task and appears in a wide range of activities (Perry, 2011). The attributes of self-confidence are confidence, attitude, and cognitive ability (Al-Nasir \& Robertson, 2001), depression (Stone et al, 2001), emotional intelligence and emotional competence, resilience (Abraham, 2004), narcissism (Campbell, Goodie, \& Foster, 2004), intuition (Korlat, 2008), doubt and uncertainty (De Cremer \& Van Hiel, 2008).

Teachers' self-confidence relates to the science background of knowledge. Teachers who have a good competency in mastering a subject or discipline might have good confidence in teaching in the classroom (Appleton, 1995). Teachers' self-confidence also relates to the teachers' self-efficacy and beliefs in which those have a significant influence, particularly to the level of teachers' self-confidence (Lemon \& Garvis, 2019). Moreover, teachers' subject matter knowledge development has an impact on the teachers' self-confidence. Subject matter knowledge development covers pedagogical content knowledge in which the teachers who have a "super-confident" feeling would be able to teach a wide range of science and select an appropriate instructional strategy (Vind, 2009). In addition, teachers' belief to be competent in answering students' questions affect negatively teachers' self-confidence (Appleton \& Kindt, 1999).

The socio-environmental aspects also have a contribution to the level of teachers' selfconfidence. Collegial can support the development of teachers' self-confidence by 
upholding teachers to try new activities and teaching strategies (Younes \& McCharty, 2007). Beside of collegial, teachers-students relationship also affects teachers' selfconfidence. Research conducted by Martin found a positive impact on teachers' perception of students' motivation and engagement towards teachers' enjoyment and confidence in teaching. This indicates the impact of the teacher-student relationship in the construction of teachers' self-confidence.

The concept of self-confidence is coincidences with the concept of self-efficacy. Selfefficacy affects a person's choice to do a particular activity and its effort and persistence (Bandura, 1977). Four factors of self-efficacy are competence, vicarious experience, verbal persuasion, and arousal (Bandura, 1986). Teachers' self-efficacy refers to a perception based and oriented to the result and it covers the context and subject matter specific (Geoghegan, 2004). Practically, scholars also found the effect of teachers' selfefficacy on work pressure and academic motivation. Research conducted by Klassen et al had found the effect of teachers' self-efficacy toward job satisfaction by examining the variable of teacher gender, years of experience, and job stress in which teachers with greater self-efficacy had greater job satisfaction (Klassen et al, 20010). Meanwhile, self-efficacy also has a relationship with academic motivation in which, self-efficacy can be improved through academic learning (Alfian et al, 2019; Fuad et al, 2019).

From those theoretical perspectives, it can be seen that the teachers' self-confidence can relate to other aspects of teachers' personal and professional skills or to other aspects of learning activities. It can be structured into internal and external factors in which it covers subject matter knowledge, collegial relationship, teachers-students relationship, and work pressure and job stress. Based on those variables, the author will analyse the construction of Indonesian Buddhist teachers' self-confidence who, as I mentioned before in the introduction, have a specific and unique problem that distinguishing them from other subject of learning.

\section{METHOD}

\section{Research Design}

The mixed-method was used as the research method. The mixed-method was a combination of qualitative with descriptive analysis approach and quantitative analysis with a factor analysis approach, practically with those respective strategies of data collection and analysis. Those methods were implemented into two phases: the qualitative phase and then the quantitative phases. The author used Maxwell and Loomis' mixed-method design approach that consists of design on the research purposes, conceptual framework, research question, methods, and validity (Maxwell \& Loomis, 2003). The author integrated the variance and process theory in this research in order to answer the research question regarding (1) what are the factors as well as the indicators that affected the self-confidence of Indonesian Buddhist teacher in performing their tasks, and (2) how strong are the significance of each factor and indicator affecting the teachers' self-confidence? The validity test was conducted by using descriptive validity and construct validity by using Aiken's V analysis. The result of Aiken's V analysis shows the result of analysis was above 0.8 , which represents its validity. 


\section{Research Participants}

The participants of the research were 153 Buddhist teachers in Central Java Province, Indonesia as the sample of the Buddhist teachers in Indonesia. The teachers teach informal education in three cities in Indonesia Wonogiri, Temanggung, and Semarang.

\section{Data Collection and Analysis}

The data were collected through a set of survey and questionnaire emphasized the aspect of self-confidence and self-efficacy of the teachers. The data were analysed through Exploratory Factor Analysis (EFA) and Confirmatory Factor Analysis (CFA), and Structure Equation Model (SEM). EFA Analysis was held in order to indicate the indicator and constituent factors of teachers' self-confidence. The CFA was held by considering the values of factor loading of 0,5. The fittest for the theoretical model and empirical data were measured based on the values of Chi-Square and RMSEA (Eisengart, 2006). SPSS and Lisrel program were used to analyse the data.

\section{FINDINGS}

\section{Qualitative Analysis of Teachers' Self-Confidence}

The result of the research shows four aspects of teachers working pressure that affected teachers' self-confidence, namely: (1) teacher-student relationship, (2) teachers' working time and additional tasks, and (3) classroom environment and learning material, (4) teachers' conflict with superiors and peers. Based on those results, it can be seen that teachers can get pressure from students, peers and superior, working time, additional tasks, and classroom environment, and learning material. Those aspects will be more explained in the following section.

\section{Teacher-student relationship}

Buddhist religious teachers have a good relationship with their students. It can be proved by the survey data that shows about $89 \%$ of teachers feels a good relationship with their students. However, about $5 \%$ of teachers recognize that the students often make an annoying attitude. About $26 \%$ of teachers perceive that their classroom is rowdy and $37 \%$ of teachers feel that the students often not pay attention to the learning process. The teachers' response to annoying students is diverse. About $89 \%$ of teachers can hold their emotions when faces annoying students, meanwhile about $11 \%$ of teachers would be mad. This data shows the small scale of the problem in the teacherstudent relationship. The problem indicates a potency of learning interruption that comes from students' characteristic that sometimes does not support the learning process. Thus, the author highlight that the problem of the teacher-student relationship can contribute to the problem of teachers' self-confidence and working performance. A poor relationship between teachers and students can provoke a working pressure; meanwhile, a good relationship can produce advantageous to the teachers' work performance and gain teachers' self-confidence. Based on this analysis, it can be summed up an early indication of the factors of teachers-students relationship that consist of (1) teachers' perception towards students, (2) students' attitude and 
characteristics, and (3) teachers' responses towards students' attitudes and characteristics.

\section{Teachers' working time and additional tasks}

The data of the research shows teachers' working time and additional tasks appear to be a contributor to their working pressure. About $16 \%$ of teachers spent too much on their working time. Moreover, about $16 \%$ of teachers feel that their working time is sufficient. About $63 \%$ of teachers feel that they do not burden with their working time. In the aspect of the additional tasks, the author noted that about $26 \%$ of teachers feel burdened by their additional tasks. Meanwhile, $26 \%$ and $47 \%$ of teachers feel that the additional tasks did not affect their working performance. Overall, the author noted that more than $16 \%$ of teachers feel burdened by their working time and additional tasks. Based on the data, the indicators of teachers' working time and additional tasks can be indicated as follow: (1) teachers' perception regarding the load of working time, (2) the load of teachers' working time, (3) teachers' perception regarding the load of their additional tasks, and (4) the load of teachers' additional tasks.

\section{Teachers' conflicts with superior and peers}

The data of the research regarding teachers' conflicts refers to the relationship between Buddhist religious teachers and their peers and superior. About $21 \%$ of teachers feel difficult to express their opinion to their superior. Moreover, about $42 \%$ of teachers feel that they should give extra attention to the dissent with their superior. About $11 \%$ of teachers feel that they not supported by their superior. Based on this data, it can be seen that teachers have a structural problem in which they have a poor relationship with their superior. This shows the potency of structural conflict even on the small scale of the conflict. Beside with superior, teachers also feel that they have conflicts with their peers. About $11 \%$ of teachers have the experience to be different from peers' opinions. About $26 \%$ of teachers do not ask help from their peers in solving their tasks. Meanwhile, about $53 \%$ of teachers do not feel that they get help from peers. About $16 \%$ of teachers have trouble communicating with their peers. Moreover, $5 \%$ of teachers feel disliked and intimidated by their peers. The data shows that the Buddhist religious teachers face structural, both in vertical and horizontal problem, with their superiors and peers. This can affect the teachers' self-confidence and work performance. It can be concluded that teachers' conflicts with superiors and peers consist of some indicators: (1) teacherssuperiors' conflict, (2) teachers-peers' conflict, (3) the interaction between teachers and their superiors and peers.

\section{Classroom environment and learning material}

The data of the research shows that $26 \%$ of Buddhist religious teachers feel the learning infrastructure has been well accommodated while $21 \%$ of the teachers feel the learning infrastructure is sufficient. On classroom availability, $21 \%$ of the teachers feel that they can do the learning process although it is held outside of the classroom. I noted that the problem of classroom availability relates to the small number of students, which only about 20 pupils, who take a part in the Buddhist religious learning process thus the schools could not provide a private classroom for Buddhist religious education 
practices. Consequently, the practice of Buddhist religious learning process could not be well implemented. This can contribute to the teachers' self-confidence and work performance.

Another issue lies in the availability of Buddhist learning material. Most of the teachers feel Buddhist learning material is insufficient. The teachers realize that Buddhist learning material could not be easily found in the bookstores. Consequently, teachers only use one book and textbook from ministry education to teach. Teachers feel that the lack of learning material affects their self-confidence particularly in teaching performance in the classroom. Teachers should be able to find another source for their learning material that feels very difficult considering other tasks of teachers. Based on this analysis, the indicators of the classroom environment and learning material can be indicated as follows: (1) teachers' perception toward availability of learning material, (2) classroom availability, (3) the quality of learning the infrastructure, and (4) teachers' perception toward infrastructure policy.

\section{Quantitative Analysis of teachers' self-confidence}

\section{Exploratory factor analysis}

Based on the qualitative analysis, the author then analysed the teachers' self-confidence through factor analysis. Firstly, the author looked at the Keiser-Meyer-Olkin Measure (KMO) analysis that shows the values 0.617 , with a Chi-Square significance level under 0.05 . The KMO values located on 0.60 to 0.69 , which means the values on the results are mediocre. The values of analysis also show that the model can be used for further analysis. The detailed of KMO analysis can be seen in table 3:

Table 3

KMO Analysis

\begin{tabular}{lll}
\hline \multicolumn{2}{l}{ Kaiser-Meyer-Olkin Measure of Sampling Adequacy. } &, 617 \\
\hline Bartlett's Test of Sphericity & Approx. Chi-Square & 2483,789 \\
& Df & 595 \\
& Sig. &, 000 \\
\hline
\end{tabular}

Based on the Exploratory Factor Analysis (EFA), it can be indicated that factors loading of teachers' self-confidence can be explained by its sub-component such as classroom environment and learning material and the teachers' working time and additional tasks. Those sub-components assist the factor of self-confidence. Each factor was arranged by four dominant indicators with the values of the loading factor greater than 0.5 . The four dominant factors of sub-component of teachers' self-confidence are (1) teachers' perception toward availability of learning material, (2) classroom availability, (3) the quality of learning the infrastructure, and (4) teachers' perception toward infrastructure policy. The values of loading factors are greater than 0.5 . Meanwhile, the four dominant factors of sub-component of teachers' self-confidence are: (1) teachers' perception regarding the load of working time, (2) the load of teachers' working time, (3) teachers' perception regarding the load of their additional tasks, and (4) the load of teachers' additional tasks. The values of loading factors are greater than 0.5 . 
The component of teachers' self-efficacy was explained by two sub-components consist of teachers' conflicts with superiors and peers and teachers-students' relationship. Those sub-components were arranged from three indicators. The three dominant factors of subcomponent of teachers' conflict with superior are (1) teachers-superiors' conflict, (2) teachers-peers' conflict, (3) the interaction between teachers and their superiors and peers. The values factors loading are greater than 0.5 . The three dominant factors of sub-component of teachers and students' relationships are as follows: (1) teachers' perception towards students, (2) students' attitude and characteristics, and (3) teachers' responses towards students' attitudes and characteristics. The values of those factors loading are greater than 0.5 .

\section{Confirmatory factor analysis}

After EFA, the author analyse the indicator through Confirmatory Factor Analysis (CFA). CFA for teachers' self-confidence shows the significance of indicators of teachers' perception toward availability of learning material (LSUASK1), classroom availability (LSUASK2), quality of learning infrastructure (LSUASK3), and teachers' perception toward infrastructure policy (LSUASK4), which can be proved by the greater values of $t$ count than $t$ table. CFA also shows the indicator significance of teachers' working time and the additional task that consist teachers' perception regarding the load of working time (TUGTAM1), the load of teachers' working time (TUGTAM2), teachers' perception regarding the load of their additional tasks (TUGTAM3), and the load of teachers' additional tasks TUGTAM4). The analysis also shows that the model is fit, which can be proved by the values of Chi-Square is $21.15>0.05, \mathrm{P}$-value is 0.32841 , and RMSEA is 0.034 . The structure model of teachers' self-confidence can be seen in figure 1 in the below:

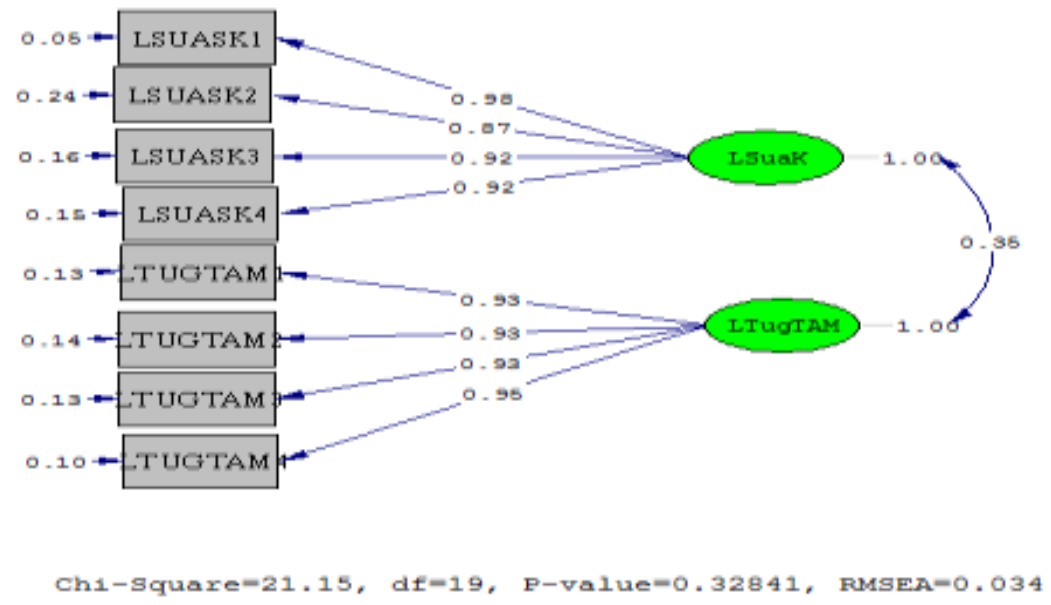

Figure 1

The Structure Model of Teachers' Self-Confidence 
CFA for teachers' self-efficacy shows the significance of the indicators of teachers' conflict with superior that consist of teachers-superiors' conflict (KONFL1), teacherspeers' conflict (KONFL2), and the interaction between teachers and their superiors and peers (KONFL3), which can be proved by the values of $t$ count that greater than table. CFA shows the significance of the indicators of teachers-students relationship that consist of teachers' perception towards students (AMBIS1), students' attitude and characteristics (AMBIS2), and teachers' responses towards students' attitudes and characteristics (AMBIS3), which can be proved by the values of $t$ count that greater than $\mathrm{t}$ table. CFA also shows the value of Chi-Square $4.87>0.05$, $\mathrm{P}$ values is 0.771 , and the value of RMSE is 0.0 . The structure model of teachers' self-efficacy can be seen in figure 2:

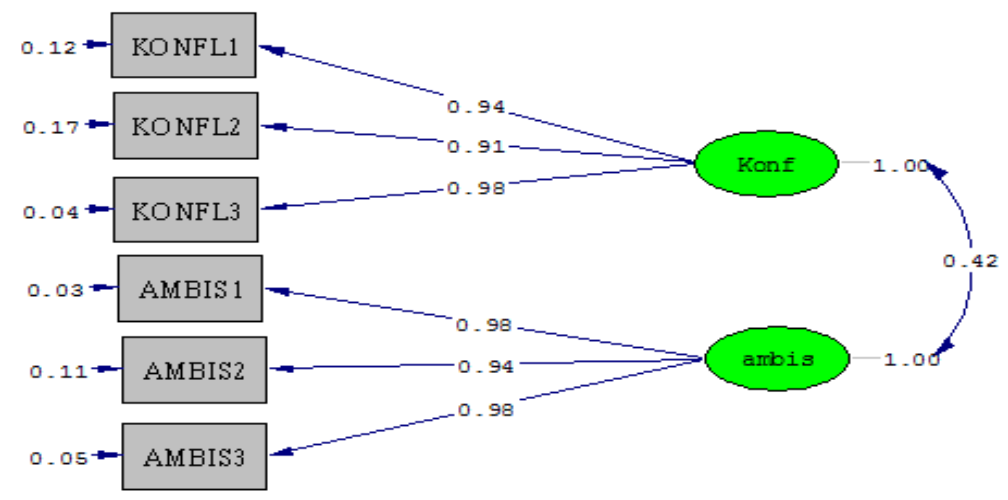

$$
\text { Chi-Square=4.87, df=8, P-value=0.77150, RMSEA=0.000 }
$$

Figure 2

The Structure of Teachers' Self-Efficacy

Based on those analyses, the data of CFA support EFA values. The values of CFA for the overall model prove the fitness of the model. It can be proved by the values of ChiSquare is $24,87>0.05$, P-value is 0.081, and the RMSEA is 0.039. Meanwhile, the value of the GFI is 0.98 . For each indicator, CFA also tends to be proving that the model is fit.

Structure Equation Model (SEM) analysis shows that the teachers' self-efficacy is influenced by peers and superior conflicts. It can be proved by the values of $t$ count (12.42) that greater than $t$ table with the values of influence is 0.69 . Teachers' selfefficacy is also influenced by the teachers-students relationship, which is showed by the values of $t$ count $(15.19)>t$ table with the values of influence is 0.82 . SEM analysis also shows that teachers' self-confidence is influenced by the classroom environment and learning material (0.49) and additional tasks (0.50). Path analysis shows that the influence of self-efficacy towards self-confidence is 0.61 . 
Based on the analysis, which was conducted through EFA, CFA, and SEM analysis, it can be concluded that factors affecting teachers' self-confidence consist of the classroom environment and learning material and teachers' working time and additional tasks. Meanwhile, factors affecting teachers' self-efficacy consist of teachers' conflict with peers and superior and teachers-students relationship. The indicators affected classroom environment and learning material are (1) teachers' perception toward availability of learning material, (2) classroom availability, (3) the quality of learning the infrastructure, and (4) teachers' perception toward infrastructure policy. The indicators affected teachers' working time and additional tasks are (1) teachers' perception regarding a load of working time, (2) a load of teachers' working time, (3) teachers' perception regarding a load of their additional tasks, and (4) a load of teachers' additional tasks. This result also proved that teachers' self-confidence is influenced by the classroom environment and learning material and teachers' working time and additional tasks.

\section{DISCUSSION}

This research shows the construction of self-confidence of Buddhist religious teachers in Indonesia that consist of several factors of the classroom environment and learning material and teachers' working time and additional tasks. These results at some point are in line with previous works on teachers' self-confidence. The indicator of teachers' perception toward availability of learning materials interline with Appleton's (1995) and Calabio et al (2017) research findings about the position of teachers' competency in mastering a subject and Vind's (2009) argumentation about the influence of subject matter knowledge and teachers' confidence. In compare, this research highlights the factors of teachers' perception toward the availability of learning material as the factors of teachers' self-confidence. It can be seen that, teachers' perception of learning material availability support teachers in mastering a subject and subject matter knowledge.

This research also emphasizes the aspect of classroom environment and teachers' working time and additional tasks as the sub-component of teachers' self-confidence. Classroom environmental refers to the learning environment, which in my research represents in the factors of classroom climates, the quality of infrastructure, and the infrastructure policy. These factors are similar to Gizir's (2019) idea about the sense of classroom belonging and the finding of Shields (2002) about the school environment, which represents the environmental support that affected teachers' self-confidence. In this research, teachers' awareness of the classroom availability, the regulation and policies, and learning environment affects the self-confidence of Indonesian Buddhist teachers. Teachers' working time and additional tasks related to a load of work and time consumption of teachers. Teachers' working time and additional tasks are inseparable from work pressure and also the potency of job burnout, motivation (Schunk, 1991), and job satisfaction (Klassen et al, 2010). In compare, this research pointed out a load of teachers' working time and additional tasks and teachers' perception of a load of teachers' working time and additional tasks.

In the practical aspect, this research supports the previous research conducted by Alfin et al, which emphasizes the development of the learning model as the strategy to 
develop self-confidence (Alfin et al, 2019). In compare with their research, this research provoked the importance of the classroom environment, the availability of learning material, and the management of working time and tasks. It means the learning model can be accompanied by a learning program that accommodates the factor of selfconfidence encompassing the learning environment, the availability of learning material, the work management and tasks. Moreover, all of those learning frameworks ideally are implemented in problem-based learning and collaborative approach (Fuad et al, 2019).

The above discussion shows that the construction of the self-confidence of Indonesian Buddhist religious teachers is interline with previous research findings. However, the Indonesian Buddhist religious teachers also have distinctive factors. This research shows the influence of external factors beyond teachers' personal and professional skills. In detail, this research revealed the structural factors that significantly affected teachers' self-confidence in the form of the classroom environment and learning material and also teachers' working time and additional tasks.

\section{CONCLUSION}

Based on the results and discussion, the author concludes two important points of my research:

1. Factors affecting the self-confidence of Indonesian Buddhist religious teachers are (a) classroom environment and learning material and (b) teachers' working time and additional tasks. The four indicators of teachers' self-confidence in the factors of the classroom environment and learning material are (1) teachers' perception toward availability of learning material, (2) classroom availability, (3) the quality of learning the infrastructure, and (4) teachers' perception toward infrastructure policy. Meanwhile, the four indicators of teachers' self-confidence in the factor of teaching working time and additional tasks are: (1) teachers' perception regarding the load of working time, (2) the load of teachers' working time, (3) teachers' perception regarding the load of their additional tasks, and (4) the load of teachers' additional tasks.

2. Each factor as well as indicator affect significantly the teachers' self-confidence. The impact can be proved by the value of loading factors which is greater than 0.5 .

This research gives an implication to the development of teachers' self-confidence, not only for Indonesian Buddhist religious teachers but also for the teachers from other subjects. This research shows that teachers' self-confidence can be understood by analyzing the classroom environment and learning material and also teachers working time and additional tasks. Therefore, this implicates the program of teachers' development that should emphasize the improvement of the classroom environment, learning material, teachers working time, and additional tasks as the important factors to develop teachers' self-confidence.

\section{RECOMMENDATION}

This research shows the importance of structural dimension, particularly in the form of classroom environmental, policy, and the availability of learning the infrastructure, in 
the construction of teachers' self-confidence. Based on that, the development of teachers' self-confidence can be initiated by providing, anticipating, preparing and a number of supporting systems in the practice of Buddhist education in Indonesia. The supporting system could be directed to the aspect of the learning infrastructure, classroom and learning material availability. Self-confidence is influenced by the policies related to the field of Buddhist education teacher work assignments. The policy can provide enthusiasm to maintain legal rules provide a sense of protection in the work that affects the teachers' self-confidence and self-efficacy.

\section{REFERENCES}

Abraham, R. (2004). Emotional competence as an antecedent to performance: A contingency framework. Genetic, Social \& General Psychology Monographs, 130, 117 143.

Al-Nasir, F. A. L., \& Robertson, A. S. (2001). Can selection assessments predict students' achievements in the premedical year: A study at Arabian Gulf University? Education for Health: Change in Learning \& Practice, 14, 277-286.

Alfin, J., Fuad, A. Z., Nur, M., Yuanita, L., \& Prahani, B. K. (2019). Development of Group Science Learning (GSL) model to improve the skills of collaborative problem solving, science process, and self-confidence of Primary Schools Teacher candidates. International Journal of Instruction, 12(1), 147-164. https://doi.org/10.29333/iji.2019.12110a.

Appleton, K., \& Kindt, I. (1999). Why teach primary science? Influences on beginning teachers' practices. International Journal of Science Education, 21(2), 155-168.

Appleton, K. (1995). Student teachers' confidence to teach science: Is more science knowledge necessary to improve self-confidence? International Journal of Science Education, 17(3), 357-369.

Bandura, A. (1977). Self-efficacy: Toward a unifying theory of behavioural change. Psychological Review, 84, 191-215.

Bandura, A. (1986). Social foundations of thought and action: A social cognitive theory. Englewood Cliffs, NJ: Prentice-Hall.

Bénabou, R., \& Tirole, J. (2002). Self-confidence and personal motivation. The Quarterly Journal of Economics, 117(3), 871-915.

Calabio, L., Khan. L., Susan, K., Tan, K., Joel. (2017) Correlation of teachers' confidence and teaching techniques to accounting interest of students. Retrieved from http://dx.doi.org/10.2139/ssrn.3006332.

Çiftçi, Ş. K., \& Yıldız, P. (2019). The effect of self-confidence on mathematics achievement: The meta-analysis of trends in international mathematics and science study (TIMSS). International Journal of Instruction, 12(2), 683-694. https://doi.org/10.29333/iji.2019.12243a 
Eisengart, S. P., et al. (2006). Factor structure of coping: Two studies of mother with high levels of life stress, Psychological Assessment, 18(3), 278-288.

Fuad, A. Z., Alfin, J., Fauzan, Astutik, S., \& Prahani, B. K. (2019). Group science learning model to improve collaborative problem solving skills and self-confidence of primary schools teacher candidates. International Journal of Instruction, 12(3), 119132. https://doi.org/10.29333/iji.2019.1238a.

Gizir, S. (2019). The sense of classroom belonging among pre-service teachers: Testing a theoretical model. European Journal of Educational Research, 8(1), 87-95.

Klassen, R. M., \& Chiu, M. M. (2010). Effects on teachers' self-efficacy and job satisfaction: Teacher gender, years of experience, and job stress. Journal of educational Psychology, 102(3), 741.

Koriat, A. (2008). Subjective confidence in one's answers: The consensually principle. Journal of Experimental Psychology/Learning, Memory \& Cognition, 34, 945-959.

Kindt, V. (2009). A conflict in your head: An exploration of trainee science teachers' subject matter knowledge development and its impact on teacher self-confidence. International Journal of Science Education, 31(11), 1529-1562.

Lemon, N., \& Garvis, S. (2019). Self-belief and confidence to teach Arts and digital technology in K-6 classrooms: Perspectives from pre-service teachers. Pre-Service and In-Service Teacher Education: Concepts, Methodologies, Tools, and Applications, 234253

Martin, A. J. (2006). The relationship between teachers' perceptions of student motivation and engagement and teachers' enjoyment of and confidence in teaching. Asia-Pacific Journal of Teacher Education, 34(1), 73-93.

Maslach, C., Jackson, S. E., Leiter, M. P., Schaufeli, W. B., \& Schwab, R. L. (1986). Maslach burnout inventory sampler set manual, general survey, human services survey, educators survey, \& scoring guides. Mind Garden Publishers.

Maxwell, J. A., \& Loomis, D. M. (2003). Mixed methods design: An alternative approach. Handbook of mixed methods in social and behavioral research, 1, 241-272.

Palmer, D. H. (2002). Factors contributing to attitude exchange amongst preservice elementary teachers. Science Education, 86(1), 122-138.

Perry, P. (2011). Concept analysis: Confidence/self-confidence. Nursing Forum 46(4), 218-230.

Purba, J., Yulianto, A., \& Widyanti, E. (2004). Pengaruh dukungan sosial terhadap burnout pada guru [Effect of social support on school teachers' burnout]. Jurnal Psikologi, 5(1), 77-87.

Sadtyadi, H. (2019). Evaluasi reflektif pengembangan karakter bangsa (Nasionalisme) dalam pendidikan Agama Buddha Tingkat Sekolah Dasar. INFERENSI: Jurnal Penelitian Sosial Keagamaan, 12(2), 371-394. 
Sadtyadi, H. (2018). Revaluasi tugas guru Pendidikan Agama Buddha dalam penguasaan dan pengembangan bahan ajar dan model penilaian. Jurnal Widyacarya, 2(1), 84-93.

Schunk, D. H., (1991). Self-efficacy and academic motivation. Educational Psychologist, 26(3-4), 207-231, doi: 10.1080/00461520.1991.9653133

Shields, C. (2002). Learning from educators: Insights into building communities of difference. In G. Furman (Ed.), School as community: From promise to practice (pp.143-162). Albany: State of New York Press.

Stone, E. R., Dodrill, C. D., \& Johnson, N. (2001). Depressive cognition: A test of depressive realism versus negativity using general knowledge questions. Journal of Psychology, 135, 583-602.

Youens, B., \& Mc Carthy, S. (2007). Subject knowledge development by science student teachers: The role of university tutors and school-based subject mentors. Research in Science and Technological Education, 25(3), 293-306.

Yu, X., Wang, P., Zhai, X. et al. (2015). The effect of work stress on job burnout among teachers: The mediating role of self-efficacy, Social Indicators Research, 122(3), 701708 . 